\title{
THE EFFECT OF ROSMARINUS OFFICINALIS L. EXTRACT ON HIGH FAT DIET-INDUCED OBESITY IN ADULT MALE ALBINO RATS
}

\author{
By \\ Ibrahim M. Shatla ${ }^{1}$, Amer M. Abdel-Hamid ${ }^{2}$ and Mahmoud Metwally ${ }^{3}$ \\ Departments of Medical Physiology $y^{1}$, Biochemistry ${ }^{2}$ and Pharmacology ${ }^{3}$, \\ Faculty of Medicine, Al-Azhar University
}

\begin{abstract}
Background: Obesity is one of the most serious global health problems of the $21^{\text {st }}$ century and it is considered as a principal risk factor in the initiation of various non-communicable chronic diseases such as dyslipidemia, atherosclerosis, cardiovascular, non-insulin dependent diabetes mellitus. Objective: The current study was designed to evaluate the effect of Rosmarinus Officinalis L. extract (RE) on serum cholesterol, HDL, LDL, TG, glucose and insulin, as well as enzymatic activity of serum GPx, SOD and catalase, body weight, adiposity index and insulin resistance in high fat diet (HFD) fed rats. Materials and Methods: Forty adult male albino rats of local strain were randomized into four equal groups. The first group was fed on basal diet and received $0.2 \mathrm{ml}$ distilled water daily by oral intubations and kept as control group. The second group was fed on basal diet and received RE ( $100 \mathrm{mg} / \mathrm{kg}$ body weight daily by oral intubations). The third group was fed on high fat diet and received $0.2 \mathrm{ml}$ distilled water by oral intubations, and the fourth group was fed on high fat diet with RE (100 mg/kg body weight daily by oral intubations). Results: Rats fed HFD showed significant increase in body weight, body weight gain, adiposity index, serum cholesterol, LDL, TG, fasting glucose, fasting insulin and HOMA-IR, and significant decrease in serum HDL and GPx, SOD and catalase in comparison to control group. Rats fed HFD with RE showed significant decrease in body weight, body weight gain, adiposity index, serum cholesterol, LDL, TG, fasting glucose, fasting insulin, and HOMA-IR, and significant increase in serum HDL, GPx, SOD and catalase in comparison to HFD group and showed significant increase in body weight, body weight gain, adiposity index, serum cholesterol, LDL, TG in comparison to control group. Rats fed basal diet with RE showed insignificant changes in comparison to control group. Conclusion: The administration of RE showed increased oxidative activities of serum SOD, GPx and catalase enzymes as well as improvement of lipid profile and decreased glucose, insulin, body weight, adiposity index, and insulin resistance in HFD fed rats.
\end{abstract}

Keywords: R officinalis extract, HFD, obesity, antioxidants, body weight, and insulin resistance.

\section{INTRODUCTION}

Obesity is an excessive fat accumulation in the body in the form of increased adipocyte number (hyperplasia) and/or increased adipocyte size (hypertrophy) (Jo et al., 2009) that results from an imbalance between energy intake and energy expenditure. It is associated with genetic, metabolic, and behavioral components, and the rapid development of obesity might reflect other problems such as dietary fat intake, fat storage and metabolism, and lifestyle (Power and Schulkin, 2008). Obesity increases the risk for many diseases including diabetes mellitus, cardiovascular diseases, hypertension (Afolayan and Mbaebie, 2010), several forms of cancer (such as breast, colon, and prostate), pulmonary, osteoarticular and metabolic diseases (PiSunyer, 2009). Consumption of a high-fat 


\section{IBRAHIM M. SHATLA et al}

diet is a major risk factor for the development of obesity. Epidemiological studies have shown that obesity is generally more prevalent in people who consume a Western-style diet, which, in addition to being deficient in several nutrients, is also high in fat (Chan and Woo, 2010).

Rosmarinus Officinalis L. ( $\mathrm{R}$ Officinalis), known as Rosemary, is a plant belonging to Labiatae (Lamiaceae) family. It is Native to the Mediterranean region, the plant is now widely distributed all over the world mainly due to its culinary, medicinal, and commercial uses (Habtemariam 2016). R. officinalis is a woody, aromatic, perennial herb with evergreen needle-like leaves, and reaching a height of $2 \mathrm{~m}$ (Socaci et al., 2007 and Orhan et al., 2008). In addition to Rosemary's role as a spice and flavoring in food, it has been traditionally consumed for its health benefits. Its aerial parts are used in oral administration to relief renal colic, and dysmenorrhea and as antispasmodic and antibacterial effect (Soyal et al., 2007 and Orhan et al., 2008). The plant has been shown to be safe and nontoxic in animal models. Because of its powerful antioxidant activity, R. Officinalis extracts are found to exhibit different protective effects as hepatoprotective, anticancer, antihyperglycemic (Bakirel et al., 2008), asthma and rheumatism (Ulbricht et al. 2010).

More than two hundred components have been identified from $R$. officinalis, which includes mainly volatile and phenolic constituents. The chemical constituents of the volatile oil fraction are complex, but most of them are monoterpenes and sesquiterpenes (OjedaSana et al., 2013). $R$. officinalis contains high percentages of phenolic diterpenes, triterpenes, phenolic acids, and flavonoids. The phenolic compounds of $R$. officinalis were reported to exert antioxidant, anti-inflammatory (Poeckel et al., 2008), antiproliferative, and antitumorigenic effects in vitro or in animal studies (Johnson et al., 2008). An evidence has shown the potential of $R$. officinalis for treatment of obesity due to its anti-hyperlipidemic effect (Sedighi et al., 2015).

The present study was demonstrated to investigate the effect of aqueous extract of R. Officinalis on serum cholesterol, HDL, LDL, TG, glucose and insulin, as well as enzymatic activity of serum GPx, SOD and catalase and body weight, adiposity index and insulin resistance in HFD fed rats.

\section{MATERIALS AND METHODS}

Animals and experimental design: Forty adult male albino rats of local strain weighing 120-150 g. Animals were kept in cages $(20 \times 30 \times 50 \mathrm{~cm}-5$ rats per cage) at room temperature, maintained on normal light/dark cycle, and fed on a commercial rat pellets and water ad libitum. They were left for two weeks for acclimatization before experimental work.

The rats were randomly divided into four equal groups as follows: Group 1 (control group) Rats were kept on a basal diet with $0.2 \mathrm{ml}$ distilled water by oral intubations, group 2 (normal/RE group) rats were kept on a basal diet and given RE $100 \mathrm{mg} / \mathrm{kg}$ body weight daily by oral intubations, group 3 (HFD group) Rats were kept on a high fat diet $(25 \%$ fat $)$ to 
induce obesity with $0.2 \mathrm{ml}$ distilled water by oral intubations, and group 4 (HFD/RE group) rats were kept on high fat diet and given RE $100 \mathrm{mg} / \mathrm{kg}$ body weight daily by oral intubations. The experiment was conducted for a period of 8 weeks.

Diet: Basal diet (Commercial rat pellets) consisted of $5.4 \%$ fat, $53.8 \%$ carbohydrate, $21.9 \%$ protein, fiber, minerals, added vitamins $\mathrm{A}, \mathrm{D}$, and $\mathrm{E}$, and cholesterol (350 kcal per $100 \mathrm{~g})$. while High fat diet consisted of $25 \%$ fat, $44.8 \%$ carbohydrate, $18.3 \%$ protein, fiber, minerals, added vitamins A, D, and E, and cholesterol (530 kcal per $100 \mathrm{~g}$ ) by adding 200 grams of sheep fat to each 1000 gram of basal diet.

Plant material: Leaves of R. Officinalis were purchased from local market in Banha. After collection, the leaves were dried for 15 days in the shade at room temperature. The dried leaves were then ground and stored in the dark. Water soluble extract was prepared. Briefly, the powder $(10 \mathrm{~g})$ was stirred in $100 \mathrm{ml}$ distilled water for 30 minutes at $50{ }^{\circ} \mathrm{C}$ followed by rapid filtration through a crude cheesecloth and then Wattman No.1 filter paper (Amin and Hamza, 2005).

Blood and tissue collection: At the end of the experiment, the overnight fasted rats were weighed; blood was collected from retro-orbital plexus of veins, left for 30 minutes to clot then centrifuged at $2000 \mathrm{rpm}$ for 15 minute to separate serum which was stored at - 20?C until It was used for measurement of the serum levels of fasting glucose, triglycerides (TG), high density lipoprotein cholesterol (HDL) \& low density lipoprotein cholesterol (LDL) were determined using enzymatic spectrophotometric technique by a kit supplied from Spinreact co. (Tietz, 1995), serum insulin was determined by ELISA research-use-only kit is an enzyme-linked immunosorbent assay designed for the quantitation using a microplate reader, the kit supplied from Thrmo Fisher Scientific (Temple et al., 1992), Superoxide Dismutase (SOD), Glutathione Peroxidase (GPx) and catalase were determined using specific Activity Assay Kit (Colorimetric) (Ann et al. 2015), The degree of insulin resistance was estimated at the baseline by HOMA according to the method described by Matthews et al. (1985), an insulin resistance score (HOMA-IR) was computed with the formula: fasting plasma glucose $(\mathrm{mmol} / \mathrm{l})$ times fasting serum insulin $(\mathrm{mU} / \mathrm{l})$ divided by 22.5 . Low HOMA-IR values indicate high insulin sensitivity, whereas high HOMAIR values indicate low insulin sensitivity. Adiposity index: After blood collection, animals were sacrificed by decapitation and adipose tissue fat pads from epididymal, retroperitoneal and visceral fat were dissected and weighed. The adiposity index was calculated as (epididymal fat + retroperitoneal fat + visceral fat /final $\mathrm{BW}) \times 100$ and expressed as adiposity percentage (Taylor and Phillips, 1996).

Statistical analysis: Data were expressed as mean \pm standard deviation (SD). Statistical analyses were carried out by using SPSS program (version 19 for windows) (SPSS Inc. Chicago, IL, USA). One-way analysis of variance (ANOVA) was used to test for significance between the groups followed by post Hoc Tukey's multiple comparison test. $\mathrm{P} \leq 0.05$ was considered statistically significant. 


\section{IBRAHIM M. SHATLA et al}

\section{RESULTS}

The results of the present study showed that administration of RE with basal diet in group 2 showed insignificant changes in the body weight, Body weight gain, adiposity index, insulin resistance (HOMA-IR), serum levels of cholesterol, LDL, HDL, TG, fasting glucose, fasting insulin, GPx, SOD and catalase in comparison to control group. In group 3, Rats fed with HFD showed significant increase in body weight, Body weight gain, adiposity index, HOMA-IR and serum levels of cholesterol, LDL, TG, fasting glucose, and fasting insulin. Also, there were significant decrease in serum GPx, SOD, catalase activity and serum HDL when compared to control rats fed on basal diet. In group 4 the administration of RE with HFD showed significant decrease in the body weight, body weight gain, adiposity index, HOMA-IR, and in serum levels of cholesterol, LDL, TG, fasting glucose, and fasting insulin. Also, there were significant increase in serum GPx, SOD and catalase activity and serum HDL in comparison to HFD group. While when compared to control rats fed on basal diet it showed significant increase in body weight, Body weight gain, and adiposity index, and in serum levels of cholesterol, LDL, TG, and significant decrease in serum HDL. Also, there were significant increase in body weight, body weight gain, adiposity index, and HOMA-IR and in serum levels of cholesterol, LDL, and TG Also, there were significant decrease in serum SOD activity and serum HDL when compared to normal/RE group.

Table (1): Effects of R Officinalis extract on body weight gain and adiposity index (Mean $\pm \mathrm{SD})$.

\begin{tabular}{|l|c|c|c|c|}
\hline Groups & $\begin{array}{c}\text { Control } \\
\text { (Group 1) }\end{array}$ & $\begin{array}{c}\text { Normal/RE } \\
\text { (Group 2) }\end{array}$ & $\begin{array}{c}\text { HFD } \\
\text { (Group 3) }\end{array}$ & $\begin{array}{c}\text { HFD/RE } \\
\text { (Group 4) }\end{array}$ \\
\hline Initial weight(g) & $135.9 \pm 18.35$ & $132 \pm 17.53$ & $136.1 \pm 16.99$ & $134.4 \pm 14.39$ \\
Final weight(g) & $197.3 \pm 21.31$ & $203.6 \pm 23.82$ & $283.3 \pm 34.64^{\mathrm{ab}}$ & $237.9 \pm 24.86^{\mathrm{abc}}$ \\
Body weight gain (g) & $61.4 \pm 4.27$ & $71.6 \pm 8.85$ & $147.2 \pm 18.26^{\mathrm{ab}}$ & $103.5 \pm 12.41^{\mathrm{abc}}$ \\
Body fat (g) & $7.13 \pm 1.04$ & $7.04 \pm 0.95$ & $14.8 \pm 1.95^{\mathrm{ab}}$ & $10.85 \pm 1.45^{\mathrm{abc}}$ \\
Adiposity index\% & $3.61 \pm 0.32$ & $3.46 \pm 0.41$ & $5.22 \pm 0.57^{\mathrm{ab}}$ & $4.56 \pm 0.33^{\mathrm{abc}}$ \\
\hline
\end{tabular}

Number of rats in each group $=10$

$\mathrm{a}=$ Significant as compared to control group.

$\mathrm{b}=$ Significant as compared to RE normal group.

$\mathrm{c}=$ Significant as compared to HFD group. 
THE EFFECT OF ROSMARINUS OFFICINALIS L. EXTRACT ON HIGH FAT... 753

Table (2): Effects of R Officinalis extract on serum levels of lipid profile (Mean \pm SD).

\begin{tabular}{|l|c|c|c|c|}
\hline \multicolumn{1}{|c|}{ Groups } & $\begin{array}{c}\text { Control } \\
\text { (Group 1) }\end{array}$ & $\begin{array}{c}\text { Normal/RE } \\
\text { (Group 2) }\end{array}$ & $\begin{array}{c}\text { HFD } \\
\text { (Group 3) }\end{array}$ & $\begin{array}{c}\text { HFD/RE } \\
\text { (Group 4) }\end{array}$ \\
\hline Cholesterol mg/dl & $103.4 \pm 17.7$ & $96 \pm 19.3$ & $187.4 \pm 28.4^{\mathrm{ab}}$ & $131.5 \pm 19.7^{\mathrm{abc}}$ \\
HDL mg/dl & $56.4 \pm 9.5$ & $59.7 \pm 7.7$ & $32.9 \pm 6.3^{\mathrm{ab}}$ & $45.1 \pm 6.9^{\mathrm{abc}}$ \\
LDL mg/dl & $38.2 \pm 2.2$ & $36.5 \pm 3.1$ & $67.8 \pm 6.7^{\mathrm{ab}}$ & $45.8 \pm 4.9^{\mathrm{abc}}$ \\
TG mg/dl & $64.5 \pm 13.4$ & $58.1 \pm 12.7$ & $137.6 \pm 19.5^{\mathrm{ab}}$ & $88.4 \pm 14.7^{\mathrm{abc}}$ \\
\hline
\end{tabular}

Number of rats in each group $=10$

$\mathrm{a}=$ Significant as compared to control group.

$\mathrm{b}=$ Significant as compared to RE normal group.

$\mathrm{c}=$ Significant as compared to HFD group.

Table (3): Effects of R Officinalis extract on serum levels of glucose, insulin and in insulin resistance (Mean $\pm \mathrm{SD})$

\begin{tabular}{|l|c|c|c|c|}
\hline \multicolumn{1}{|c|}{ Groups } & $\begin{array}{c}\text { Control } \\
\text { (Group 1) }\end{array}$ & $\begin{array}{c}\text { Normal/RE } \\
\text { (Group 2) }\end{array}$ & $\begin{array}{c}\text { HFD } \\
\text { (Group 3) }\end{array}$ & $\begin{array}{c}\text { HFD/RE } \\
\text { (Group 4) }\end{array}$ \\
\hline Glucose mg/dl & $83.2 \pm 8.93$ & $78.9 \pm 11.55$ & $127.5 \pm 17.8^{\text {ab }}$ & $94.9 \pm 13.82^{\mathrm{c}}$ \\
Insulin ? IU/ml & $7.62 \pm 1.15$ & $6.83 \pm 1.43$ & $13.95 \pm 2.37^{\mathrm{ab}}$ & $8.68 \pm 1.64^{\mathrm{c}}$ \\
HOMA-IR & $1.56 \pm 0.24$ & $1.32 \pm 0.29$ & $4.32 \pm 0.58^{\mathrm{ab}}$ & $2.05 \pm 0.58^{\mathrm{bc}}$ \\
\hline
\end{tabular}

Number of rats in each group $=10$

a =Significant as compared to control group.

$\mathrm{b}=$ Significant as compared to RE normal group.

$\mathrm{c}=$ Significant as compared to HFD group.

Table (4): Effects of R Officinalis extract on serum antioxidative enzymes activity (Mean $\pm \mathrm{SD})$

\begin{tabular}{|l|c|c|c|c|}
\hline \multicolumn{1}{|c|}{ Groups } & $\begin{array}{c}\text { Control } \\
\text { (Group 1) }\end{array}$ & $\begin{array}{c}\text { Normal/RE } \\
\text { (Group 2) }\end{array}$ & $\begin{array}{c}\text { HFD } \\
\text { (Group 3) }\end{array}$ & $\begin{array}{c}\text { HFD/RE } \\
\text { (Group 4) }\end{array}$ \\
\hline GPx IU/ml & $5.47 \pm 0.64$ & $5.54 \pm 0.92$ & $3.4 \pm 0.62^{\mathrm{ab}}$ & $4.97 \pm 1.01^{\mathrm{c}}$ \\
SOD U/ ml & $240.2 \pm 37.5$ & $257 \pm 40.4$ & $\begin{array}{c}134.9 \pm 21.69 \\
\mathrm{ab}\end{array}$ & $206.7 \pm 29.54^{\mathrm{bc}}$ \\
Catalase U/ ml & $127.6 \pm 20.88$ & $139.6 \pm 24.51$ & $67.5 \pm 12.73^{\mathrm{ab}}$ & $117 \pm 23.8^{\mathrm{c}}$ \\
\hline
\end{tabular}

Number of rats in each group $=10$,

$\mathrm{a}=$ Significant as compared to control group.

$\mathrm{b}=$ Significant as compared to RE normal group.

$\mathrm{c}=$ Significant as compared to HFD group. 


\section{IBRAHIM M. SHATLA et al}

\section{DISCUSSION}

In the present study, $\mathrm{R}$ officinalis administration in normal rats led to insignificant change in the body weight, body weight gain and adiposity index when compared to control group. Feeding rats with HFD or HFD with R officinalis extract significantly increased body weight, body weight gain and adiposity index when compared to control group, while HFD with R officinalis extract led to significant decrease in the body weight, body weight gain and adiposity index when compared to HFD group.

Our results were in agreement with Shokrollahi et al. (2015) who found that no significant differences were seen in body weight and total gain in animals received $\mathrm{R}$ officinalis extract when compared to control group. Also, agreed with Handjieva-Darlenska and Boyadjieva (2009) and Ibarra et al. (2011), there was a significant effect of the high-fat diet on the body weight in the experimental group, which showed higher body weight increase compared to control group. Priego et al. (2009) stated that HFD increase body weight and adiposity index. Ibarra et al. (2011) and Runtuwene et al. (2016) stated that body weight gain and accumulated body fat significantly decreased in HFD/RE group when compared to HFD group but still significantly increased when compared to control group. Limiting lipid absorption is a potential mechanism by which RE decreased weight gain and adiposity index which is strongly supported by evidence of the in vitro inhibitory effect of RE on pancreatic lipase activity, a key enzyme in the digestion and absorption of fat (Ibarra et al., 2011), and on gastric lipase activity
Vaquero et al. (2012). Also, RE enriched in CA modifies the microbiota composition and $\beta$-glucosidase activity in the caecum of the obese rats increasing the main short chain fatty acids excreted in the feces (Romo-Vaquero et al., 2014). CA has also been reported to inhibit adipocyte differentiation by blocking CCAAT/enhancer-binding protein $\alpha(\mathrm{C} / \mathrm{EBP} \alpha)$ and peroxisome proliferator-activated receptor $\gamma(\operatorname{PPAR} \gamma)$ pathways (Gaya et al., 2013).

The increased plasma cholesterol, particularly LDL-c, is one of the most important risk factor for coronary vascular disease. LDL-c particles are taken up by macrophage cells after oxidized or modified and then deposited in the arterial intima leading to formation of atheroma. Low HDL-c levels are considered as a strong risk factor for coronary heart disease as HDL-c act as antioxidant and protect LDL-c from oxidation so that reduce LDL-c from circulation (Libby et al., 2011). It has been postulated that decrease in serum cholesterol by $1 \%$ reduces the risk of chronic heart disease by $2 \%$ (Jain et al., 2007). The current study showed insignificant change in the serum levels of cholesterol, LDL, TG and HDL in rats received $\mathrm{R}$ officinalis extract with basal diet. There were significant increases in the levels of serum cholesterol, LDL, TG, and significant decrease in serum HDL in HFD and HFD/RE groups as compared to control group, while HFD/RE showed significant decrease in the levels of serum cholesterol, LDL, TG and significant increase in serum HDL when compared to HFD group. 
These results were concomitant with Aljamal et al. (2012) and Alnahdi (2012) who reported that R. officinalis has no significant influence on serum level of serum cholesterol, LDL, HDL and TG of normal rats. It ameliorated disturbed lipid profile in diabetic rats in which it significantly reduced cholesterol, triglycerides, LDL and increased HDL. Venkateshan et al. (2016) stated that HFD fed rats showed significant increase in plasma cholesterol, TG, LDL and decrease in HDL Ibarra et al. (2011) and Vaquero et al. (2012) showed that RE significantly reduced elevated $\mathrm{TG}$ and cholesterol levels induced by the HFD. Al Sheyab et al. (2012) reported that the oral administration of Rosemary plant extracts to high cholesterol-fed mice (HC) resulted in significant declines of plasma total cholesterol, LDL-C, and TG as compared to $\mathrm{HC}$ mice, while there was an increase in HDL in comparison to $\mathrm{HC}$ mice. Labban et al. (2014) reported that $\mathrm{R}$. officinalis appears to improve not only hyperglycemia but also dyslipidemia and decreases lipid peroxidation through increasing antioxidants levels. Our results disagreed with Handjieva-Darlenska and Boyadjieva (2009) who reported that no difference in the lipid parameters were registered between normal and HFD fed rats. This disagreement may be due to differences in strains, concentration of fat in HFD, or period of the experiment.

Hypolipidemic effect of $\mathrm{R}$ officinalis extract might be due to inhibition of pancreatic lipase activity (Ibarra et al. 2011), and gastric lipase activity (Vaquero et al., 2012) decreasing digestion and absorption of fat. Moreover, $\mathrm{R}$ officinalis extract inhibits hormone sensitive lipase (Bustanji et al., 2010) which is an intracellular neutral lipase catalyzes the hydrolysis of triglycerides and cholesteryl esters leading to efflux of free fatty acids and cholesterol from the adipocytes (Ahmadian et al., 2007). Adipose HSL activity is normally inhibited by insulin. Decreasing insulin resistance may play an additional role of HSL inhibition of R. officinalis extract in vivo. Also, Rosemary extract activated both AMPK and PPAR pathways, thereby regulating lipid metabolism (Zheng et al., 2013).

In the current study, R. officinalis administration in normal rats led to insignificant changes in the serum levels of fasting glucose, fasting insulin and HOMA-IR when compared to control group. There was a significant increase in the levels of serum glucose, serum insulin and HOMA-IR in HFD fed rats as compared to control group. Rats with HFD and $\mathrm{R}$ officinalis extract showed significant decrease in the levels of serum glucose, serum insulin and HOMA-IR when compared to HFD fed rats, while it showed insignificant changes when compared to control group.

These findings were in agreement with those observed by Ibarra et al. (2011), Aljamal et al. (2012) and Alnahdi (2012) who reported that Rosemary leaf extract has no significant influence on serum glucose level of normal rats. It also agreed with Handjieva-Darlenska and Boyadjieva (2009) and Ibarra et al. (2011) who stated that high fat diet produced higher blood glucose level in experimental rats in comparison to control rats. Runtuwene et al. (2016) found that HFD fed rats showed significant increase of plasma glucose, insulin levels and 
insulin resistance, while fasting hyperglycaemia reduced in animals in the HFD/ Rosmarinic acid group compared with the HFD group. These findings were parallel to that of Ibarra et al. (2011) who found that Rosmarinic acid decreases hyperglycemia, insulin level and insulin resistance in HFD fed rats. The results disagreed with Ibarra et al. (2011) who found that no significant differences were observed in insulin levels HFD or HFD/RE when compared to control groups. This disagreement may be due to differences in strains, concentration of fat in HFD, or period of the experiment.

The possible mechanism of antihyperglycemic action of $\mathrm{R}$ officinalis is phosphoenolpyruvate carboxykinase (PEPCK) expression, an enzyme in the lyase family used in the metabolic pathway of gluconeogenesis (MéndezLucas et al., 2014), markedly increased in isolated liver cells in both the diabetic and HFD-fed rats. Rosmarinic acid (RA) treatment reduced hepatic PEPCK expression in both groups, suggesting that RA decreased gluconeogenesis in the livers of diabetic rats. Additionally, GLUT4 expression was significantly lower in both diabetic rats and the HFDfed rats. RA treatment markedly increased GLUT4 expression in both groups. Both mechanisms decrease glucose output by the liver and increase glucose uptake by skeletal muscles decreasing blood glucose, serum insulin levels and HOMAIR (Runtuwene et al., 2016). High-fat diet induced obesity was associated with the increased expression of SGLT-1 in rats, the key molecule in glucose absorption (Huang et al., 2012). R officinalis may control plasma glucose by decreasing intestinal glucose transport by inhibiting glucose SGLT1 trafficking to the intestinal brush-border membrane (Azevedo et al., 2011). Furthermore, the altered activities of key carbohydrate metabolizing enzymes such as hexokinase, pyruvate kinase, glucose-6phosphatase, fructose 1,6-bisphosphatase, glucose-6-phosphate dehydrogenase, glycogen synthase and glycogen phosphorylase in the liver tissue were significantly reverted to near normal levels upon treatment with RA (Jayanthy et al., 2014). Other probable mechanism of anti-hyperglycemic action is the effect of $\mathrm{R}$ officinalis extract on two critical pathways in glucose and lipid metabolic regulation, AMP activated protein kinase (AMPK) and peroxisome proliferated activated receptor (PPAR), where AMPK is a serine/threonine kinase that functions as an intracellular energy sensor, activated under conditions of low energy, such as elevated AMP/ATP ratio (Hardie, 2011). The activation of AMPK switches off anabolic pathways that consume ATP, such as fatty acid, glycogen, and cholesterol synthesis, and switches on catabolic pathways that generate ATP, such as fatty acid oxidation and glycolysis (Steinberg and Kemp, 2009). While nuclear PPAR receptors function as sensors for fatty acids and fatty acid derivatives and control expressions of many essential genes in the regulation of cellular lipid metabolism, differentiation, storage and development (Varga et al., 2011 and Rigano et al., 2017). R officinalis extract activates both AMPK and PPAR pathways, thereby regulating glucose metabolism (Zheng et al., 2013). Reactive oxygen species (ROS) such as hydrogen peroxide, nitric oxide, superoxide and the highly reactive 
hydroxyl radicals and reactive nitrogen species (RNS) are naturally generated in biological systems(Lobo et al., 2010). Its production is counteracted by the intrinsic antioxidant defense, both enzymatic and non-enzymatic, which protects against free radicals and the subsequent cell damage(Birben et al., 2012). Oxidative damage occurs as an imbalance between the production of ROS and the ability of intrinsic antioxidant systems to scavenge these radicals. Oxidation of macromolecules such as proteins, lipids and DNA may lead to cell degeneration and death due to an increase in the release of apoptotic inducing factors (Pickering et al., 2013) and loss of cell membrane integrity and function (Rasoul et al., 2016).

Our study showed insignificant changes in the activities of serum GPx, SOD and catalase in normal rats received RE when compared to control group. There were significant decreases in the activities of serum antioxidant enzymes GPx, SOD and catalase in in HFD as compared to control group. HFD/RE showed insignificant changes in the activities of serum GPx, SOD and catalase as compared to control group and significant increase when compared to HFD group. The results disagreed with Rasoolijazilet al. (2015) who stated that GPx, SOD and CAT activities significantly increased in the hippocampus of rats received RE compared to the normal group, the disagreement may be due to that the used form was Rosemary extract boosted by $40 \%$ carnosic acid and administration for 12 weeks. These findings were supported by Chauhan et al. (2012) who attributed that activities of enzymatic antioxidants
GPx, SOD, CAT decreased in the liver of animals fed HFD which is probably due to detrimental effects due to accumulation of superoxide radical and $\mathrm{H}_{2} \mathrm{O}_{2}$. Bak?rel et al. (2008) reported that treatment of diabetes with the R. officinalis extract had reversed the decreased activities of enzymatic antioxidants, which might be due to decreased oxidative stress as evidenced by decreased lipid peroxidation. These results were in accordance with that reported by Govindaraj and Pillai (2015) who stated that the diminished activities of pancreatic SOD, catalase, and GPx in STZ-diabetic rats significantly recovered near normalcy upon RA treatment. Hyperglycemia induces free radicals and impairs the endogenous antioxidant defense system (Matough et al., 2012) by formation of advanced glycation end products which significantly decreased the activities of enzymatic antioxidant such as SOD and CAT (Ren et al., 2017). It is also supported by the study of Ozturk et al. (2014) which reported that ischemia/ reperfusion process exhausts the free radical scavenging system decreasing tissue anti-oxidant enzymes, SOD, and GPx leading to elevated superoxide and hydrogen peroxide levels which accelerate the renal damage while treatment with RA attenuate I-R injury by increasing the activities of serum SOD and GPx which also provid by histological examination. Rasoul et al. (2016) observed that $\mathrm{RE}$ could decrease oxidative stress by significantly increasing the activities of SOD, CAT and GPx in hippocampus resulting in the decrease of lipid peroxidation level. Rosmarinic acid can 
provide substantial cytoprotection against peroxidative damage by modulating cellular antioxidant systems (Fernando et al., 2016). Additionally, Sharmila et al. (2012) reported that rosmarinic acid had potent anti-lipid peroxidative and apoptotic effect in skin carcinogenic mice models. It has been shown in an in vitro study that carnosic acid has direct action as an antioxidant (Azad et al., 2011). Most pharmacological effects of $\mathrm{R}$. officinalis are the consequence of high antioxidant activity of its main chemical constituents, which include carnosol, carnosic acid, ursolic acid, rosmarinic acid, and caffeic acid (Ngo et al., 2011). The compounds responsible for antioxidative activity of Rosmarinus officinalis are mainly phenolic diterpenes such as carnosoic acid, carnosol, rosmanol (Amar et al., 2017), and other phenolic acids, such as rosmarinic and caffeic acids (Terpinc et al., 2009). It has been reported that the antioxidant activity of such RE phenolic compounds was related to their hydroxyl group in addition to the presence of a second hydroxyl group in the ortho or para position which is known to increase the antioxidative activity due to additional resonance stability (Sakr et al., 2010). Carnosic acid, carnosol and rosmarinic acid have o-hydroxyl group and possessed high antioxidative activity (Abdella and Ahmed, 2009). The mechanisms for protection of RE phenolic compounds involves scavenging potentially toxic and free radicals that modulate activation of extra-cellular signaling protein, tumor necrosis factor (TNF), a major mediator of apoptosis and inflammatory response and enhance high antioxidative activity pathways (Chang et al., 2008).

\section{CONCLUSION}

HFD decreased levels of serum HDL and activities of serum antioxidative enzymes SOD, GPx and catalase as well as increased serum cholesterol, LDL, TG, glucose, insulin, body weight, adiposity index, and insulin resistance while $\mathrm{R}$ officinalis extract increased levels of serum HDL and activities of serum antioxidative enzymes SOD, GPx and catalase as well as decreased serum cholesterol, LDL, TG, glucose, insulin, body weight, adiposity index, and insulin resistance in HFD fed rats.

\section{REFERENCES}

1. Abdella, EM. and Ahmed, R. (2012): Suppression of Doxorubicin Apoptotic, Histopathologic, Mutagenic and Oxidative Stress Effects in Male Mice Bone Marrow and Testis Tissues by Aqueous Rosemary Leaves Extract. IJCP, 2 (1): 35-49.

2. Afolayan, H.J. and Mbaebie, BO. (2010): Ethnobotanical study of medicinal plants in Nkonkobe Municipality in South Africa. Pharmacognosy Journal, 2 (11): 368- 374.

3. Ahmadian, M., Robin, E., Duncan, Jaworski K., Sarkadi-Nagy E. and Sul, H. (2007): Triacylglycerol metabolism in adipose tissue. Future Lipidol, 2 (2): 229-237.

4. Al Sheyab, F.M., Abuharfeil, N., Salloum, L., Hani, R. and Awad, D.S. (2012): The Effect of Rosemary (Rosmarinus officinalis. L) Plant Extracts on the Immune Response and Lipid Profile in Mice. Journal of Biology and Life Science, 3 (1): 2157-6076.

5. Aljama, A., Ibrahim, A., Al-Fararjeh, MA. and Alqadi, T. (2012): Effects of rosemary on lipid profile in diabetic rats. African Journal of Plant Science, 6 (7): 222-225.

6. Alnahdi, H.S. (2012): Effect of Rosmarinus Officinalis Extract on some Cardiac Enzymes 
THE EFFECT OF ROSMARINUS OFFICINALIS L. EXTRACT ON HIGH FAT...

of Streptozotocin-induced Diabetic Rats. Journal of Health Sciences, 2(4): 33-37.

7. Amar, Y., Meddah, B., Bonacorsi, I., Costa, G., Pezzino, G., Saija, A. and Meddah, A. T. (2017): Phytochemicals, Antioxidant and Antiproliferative Properties of Rosmarinus officinalis L on U937 and CaCo-2 Cells. Iranian Journal of Pharmaceutical Research, 16 (1): 315-327.

8. Amin, A. and Hamza, AA. (2005): Hepatoprotective effects of Hibiscus, Rosmrinus and Salvia on azathioprine-induced toxicity in rats. Life Sciences, 77: 266-278.

9. Ann, J.Y., Eo, H. and Lim, Y. (2015): Mulberry leaves (Morus alba L.) ameliorate obesity-induced hepatic lipogenesis, fibrosis, and oxidative stress in high-fat diet-fed mice. Genes Nutr., 10(6): 46.

10. Azad, N., Rasoolijazi, H., Joghataie, MT. and Soleimani, S. (2011): Neuroprotective effects of carnosic Acid in an experimental model of Alzheimer's disease in rats. Cell J., 13(1):39-44.

11. Azevedo, MF., Lima, CF., FernandesFerreira, M., Almeida, MJ., Wilson, JM. and Pereira-Wilson, C. (2011): Rosmarinic acid, major phenolic constituent of Greek sage herbal tea, modulates rat intestinal SGLT1 levels with effects on blood glucose. Mol Nutr Food Res., 55 (Suppl 1):S15-S25.

12. Bakirel, T., Bakirel, U., Keles, OU., Ulgen, SG. and Yardibi H. (2008): In vivo assessment of antidiabetic and antioxidant activities of rosemary (Rosmarinus officinalis) in alloxan-diabetic rabbits. Journal of Ethnopharmacology, 116: 64-73.

13. Birben, E., Sahiner, U.M., Sackesen, C., Erzurum, S. and Kalayci O. (2012): Oxidative Stress and Antioxidant Defense. The World Allergy Organization Journal, 5(1): 9-19.

14. Bustanji, Y., Issa, A., Mohammad, M., Hudaib, M., Tawah, K., Alkhatib, H., Almasri, I. and Al-Khalidi, B. (2010): Inhibition of hormone sensitive lipase and pancreatic lipase by Rosmarinus officinalis extract and selected phenolic constituents.
Journal of Medicinal Plants Research, 4(21): 2235-2242.

15. Chan, R. S., and Woo, J. (2010): Prevention of overweight and obesity: How effective is the current public health approach. International Journal of Environmental Research and Public Health, 7(3): 765-783.

16. Chang, C., Chyau, C., Hsieh, C., Wu, Y., Ker, Y., Tsen, H. and Peng, R. (2008): Relevance of phenolic diterpene constituents to antioxidant activity of supercritical $\mathrm{CO} 2$ extract from the leaves of rosemary. Nat. Prod. Res., 10: 22(1):76-90.

17. Chauhan, K., Sharma, S., Agarwal, N., Chauhan, S. and Chauhan, B. (2012): A study on potential hypoglycemic and hypolipidemic effects of Lepidium Sativum (Garden Cress) in Alloxan induced diabetic rats. American Journal of PharmTech Research, 2: 522-535.

18. Fernando, P. M., Piao, M. J., Kang, K. A., Ryu, Y. S., Hewage, S. R., Chae, S. W. and Hyun, J. W. (2016): Rosmarinic Acid Attenuates Cell Damage against UVB Radiation-Induced Oxidative Stress via Enhancing Antioxidant Effects in Human HaCaT Cells. Biomolecules and Therapeutics, 24(1):75-84.

19. Gaya, M., Repetto, V., Toneatto, J., Anesini, C., Piwien-Pilipuk, G. and Moreno S. (2013): Antiadipogenic effect of carnosic acid, a natural compound present in Rosmarinus officinalis, is exerted through the C/EBPs and PPAR $\gamma$ pathways at the onset of the differentiation program. Biochim Biophys Acta, 1830:3796-3806.

20. Govindaraj, J. (2015): Subramanian Sorimuthu PillaiRosmarinic acid modulates the antioxidant status and protects pancreatic tissues from glucolipotoxicity mediated oxidative stress in high-fat diet: streptozotocin-induced diabetic rats. Mol. Cell Biochem., 404(1-2): 143-59.

21. Habtemariam, S. (2016): The Therapeutic Potential of Rosemary (Rosmarinus Officinalis) Diterpenes for Alzheimer's Disease. Evidence-Based Complementary and Alternative Medicine, 1:1-14. 
22. Handjieva-Darlenska, T. and N. Boyadjieva (2009): The effect of high-fat diet on plasma ghrelin and leptin levels in rats. J. Physiol. Biochem., 65 (2): 157-164.

2. Hardie, D. G. (2011): AMP-activated protein kinase-an energy sensor that regulates all aspects of cell function. Genes \& Development, 25(18): 1895-1908.

24. Huang, W., Liu, R., Guo, W., Wei, N., Qiang, O., Li, X., Ou, Y. and Tang, C. (2012): Impact of high-fat diet induced obesity on glucose absorption in small intestinal mucose in rats. Wei Sheng Yan Jiu, 41 (6): 878-82.

25. Ibarra, A., Cases, J., Roller, M., ChiraltBoix, A., Coussaert, A. and Ripoll, C. (2011): Carnosic acid-rich rosemary (Rosmarinus officinalis L.) leaf extract limits weight gain and improves cholesterol levels and glycaemia in mice on a high-fat diet. British Journal of Nutrition, 106(8): 1182-9.

26. Jain, KS., Kathiravan, MK., Somani, RS., and Shishoo, CJ. (2007): The biology and chemistry of hyperlipidemia. Bioorganic and Medicinal Chemistry, 15: 4674-4699.

27. Jayanthy, G. and Subramanian, S. (2014): Rosmarinic acid, a polyphenol, ameliorates hyperglycemia by regulating the key enzymes of carbohydrate metabolism in high fat diet STZ induced experimental diabetes mellitus. Biomed Prev Nutr., 4(3): 431-437.

28. Jo, J., Gavrilova, O., Pack, S., Jou, W., Mullen, S., Sumner, A. E., Samuel W. Cushman, and Periwal, V. (2009): Hypertrophy and/or Hyperplasia: Dynamics of Adipose Tissue Growth. PLoS Computational Biology, 5(3): e1000324.

29. Johnson, JJ., Syed, DN., Heren, CR., Suh, Y., Adhami, VM. and Mukhtar, H. (2008): Carnosol, a dietary diterpene, displays growth inhibitory effects in human prostate cancer PC3 cells leading to G2-phase cell cycle arrest and targets the 5'-AMP-activated protein kinase (AMPK) pathway. Pharm Res., 25(9): 2125-34.

30. Labban, L., Mustafa, U.E. and Ibrahim, Y.M. (2014): The Effects of Rosemary (Rosmarinus officinalis) Leaves Powder on
Glucose Level, Lipid Profile and Lipid Perodoxation. International Journal of Clinical Medicine, 5: 297-304.

31. Libby, P., Ridker, P. M. and Hansson, G. K. (2011): Progress and Challenges in Translating the Biology of Atherosclerosis. Nature, 473:317-25.

32. Lobo, V., Patil, A., Phatak, A. and Chandra, N. (2010): Free Radicals, Antioxidants and Functional Foods: Impact on Human Health. Pharmacogn., 4(8): 118-26.

33. Matough, F. A., Budin, S. B., Hamid, Z. A., Alwahaibi, N. and Mohamed, J. (2012): The Role of Oxidative Stress and Antioxidants in Diabetic Complications. Sultan Qaboos University Medical Journal, 12(1): 5-18.

34. Matthews, DR., Hosker, JP., Rudenski, AS., Naylor, BA., Treacher, DF. and Turner, RC. (1985): Homeostasis model assessment: insulin resistance and beta-cell function from fasting plasma glucose and insulin concentrations in man. Diabetologia, 28: 412419.

35. Méndez-Lucas, A., Hyro??ov?, P., Novellasdemunt, L., Vi?als, F. and Perales, JC. (2014): "Mitochondrial phosphoenolpyruvate carboxykinase (PEPCK-M) is a prosurvival, endoplasmic reticulum (ER) stress response gene involved in tumor cell adaptation to nutrient availability". J. Biol. Chem., 289 (32): 22090-102.

36. Ngo, S.N., Williams D.B. and Head R.J. (2011): Rosemary and cancer prevention: preclinical perspectives. Crit. Rev. Food Sci. Nutr., 51: 946-954.

37. Ojeda-Sana, AM., van Baren, CM., Elechosa, MA., Jua' rez, MA. and Moreno, S. (2013): New insights into antibacterial and antioxidant activities of rosemary essential oils and their main components. Food Control, 31:189-195.

38. Orhan, I., Aslan, S., Kartal, M., Sener, B. and Baser, KHC. (2008): Inhibitory effect of Turkish Rosmarinus officinalis L. on acetylcholinesterase and utyrylcholinesterase enzymes. Food Chemistry, 108: 663-668.

39. Ozturk, H., Ozturk, H., Terzi, E.H., Ozgen, U., Duran, A. and Uygun, I. (2014): 
THE EFFECT OF ROSMARINUS OFFICINALIS L. EXTRACT ON HIGH FAT...

Protective effects of Rosmarinic acid against renal ischaemia/reperfusion injury in rats. $\mathrm{J}$. Pak. Med. Assoc., 64 (3): 260-265.

40. Pickering, A. M., Vojtovich, L., Tower, J. and Kelvin, J. A. (2013): Oxidative Stress Adaptation with Acute, Chronic, and Repeated Stress. Free Radical Biology and Medicine, 55: 109-18.

41. Pi-Sunyer, X. (2009): The Medical Risks of Obesity. Postgraduate Medicine, 121(6): 2133.

42. Poeckel, D., Greiner, C., Verhoff, M., Rau, O., Tausch, L., Hornig, C., Steinhilber, D., Schubert-Zsilavecz, M. and Werz $O$. (2008): Carnosic acid and carnosol potently inhibit human 5-lipoxygenase and suppress pro-inflammatory responses of stimulated human polymorphonuclear leukocytes. Biochem. Pharmacol., 76: 91-97.

43. Power, ML. and Schulkin, J. (2008): Sex differences in fat storage, fat metabolism, and the health risks from obesity:Possible evolutionary origins. Br J Nutr., 99:931-40.

44. Priego, T., J. S?nchez, A. Palou. and C. Pic? (2009): Effect of high-fat diet feeding on leptin receptor expression in white adipose tissue in rats: depot- and sex-related differential response. Genes Nutr., 4(2): 151156.

45. Rasoolijazi, H., Mehdizadeh, M., Soleimani, M., Nikbakhte, F., Eslami Farsani, M. and Ababzadeh, S. (2015): The effect of rosemary extract on spatial memory, learning and antioxidant enzymes activities in the hippocampus of middle-aged rats. Med J Islam Repub Iran, 29:187.

46. Rasoul, A., GhasemKashani M., Mohammad TG., Taghi L. and Dehghan R. (2016): Antioxidant Activity of Oral Administration of Rosmarinus Officinalis Leaves Extract on Rat's Hippocampus which Exposed to 6Hydroxydopamine. Braz. Arch. Biol. Technol. 59: e16150354.

47. Ren, X., Ren, L., Wei, Q., Shao, H., Chen, L., and Liu, N. (2017): Advanced glycation end-products decreases expression of endothelial nitric oxide synthase through oxidative stress in human coronary artery endothelial cells. Cardiovascular Diabetology, 16: 52 .

48. Rigano, D., Sirignano, C. and TaglialatelaScafati, O. (2017): The potential of natural products for targeting PPAR $\alpha$. Acta. Pharm. Sin. B., 7(4): 427-438.

49. Romo-Vaquero, M., Y??ez-Gasc?n, M., Villalba, R., Larrosa, M., Fromentin, E., Ibarra, A., Roller, M., Tom?s-Barber?n, F., Esp?n, J.C. and Garca-Conesa, M. (2012): Inhibition of Gastric Lipase as a Mechanism for Body Weight and Plasma Lipids Reduction in Zucker Rats Fed a Rosemary Extract Rich in Carnosic Acid. PLoS One, 7(6): e39773.

50. Romo-Vaquero, M.,.Selma, M, Larrosa, M., Obiol, M., Garch-Villalba, R. and Gonz?lez-Barrio, R. (2014): A Rosemary Extract Rich in Carnosic Acid Selectively Modulates Caecum Microbiota and Inhibits $\beta$ Glucosidase Activity, Altering Fiber and Short Chain Fatty Acids Fecal Excretion in Lean and Obese Female Rats. PLOS One, 9(4): e94687.

51. Runtuwene, J., Cheng, A., Asakawa, H., Amitani, A., Amitani, M., Morinaga, K., Akimoto, Y., Kairupan, B. and Inui, K. (2016): Rosmarinic acid ameliorates hyperglycemia and insulin sensitivity in diabetic rats, potentially by modulating the expression of PEPCK and GL UT4. Drug Design, Development and Therapy, 10: 21932202.

52. Sakr, S. A., El-Abd, S. F., Osman, M., Kandil, A. M. and Helmy M. S. (2010): Effect of Rosemary on carbon tetrachlorideinduced hepatotoxicity in albino rats: Histological and Biochemical studies. Egypt. J. Exp. Biol. (Zoo.), 6(1): 135-140.

53. Sedighi, R., Zhao, Y., Yerke, A. and Sang, S. (2015): Preventive and protective properties of rosemary (Rosmarinus officinalis L.) in obesity and diabetes mellitus of metabolic disorders: a brief review. Current Opinion in Food Science, 2: 58-70.

54. Sharmila, R. and Manoharan, S. (2012): Anti-tumor activity of rosmarinic acid in 7,12dimethylbenz(a)anthracene (DMBA) induced 
skin carcinogenesis in Swiss albino mice. Indian J Exp Biol., 50(3): 187-194.

55. Shokrollahi, B., Amini, F., Fakour, S. and Andi, MA. (2015): Effect of rosemary (Rosmarinus officinalis) extract on weight, hematology and cell-mediated immune response of newborn goat kids. Journal of Agriculture and Rural Development in the Tropics and Subtropics, 116 (1): 91-97

56. Socaci, AS., Maria, T., Carmen, S., Varban, D. and Sevastita, M. (2007): Comparative Study of Different Rosemry Essential Oil. Bulletin USAMV-CN., 63: 591- 595.

57. Soyal, D., Jindal, A., Singh, I. and Goyal, PK. (2007): Modulation of radiation-induced biochemical alterations in mice by rosemary (Rosmarinus officinalis) extract. Phytomedicine, 14 (10): 701-705.

58. Steinberg, G.R. and Kemp, B.E. (2009): AMPK in health and disease. Physiol. Rev., 89: 1025-1078.

59. Taylor, B.A. and Phillips, S.J. (1996): Detection of obesity QTLs on mouse chromosomes 1 and 7 by selective DNA pooling. Genomics,34: 389-398.

60. Temple, R., Clark P.M.S. and Hales, C.N. (1992): Measurement of Insulin Secretion in Type 2 Diabetes: Problems and Pitfalls. Diabetic Medicine, 9: 503-512.

61. Terpinc, P., Bezjak, M. and Abramovič, $H$. (2009): A kinetic model for evaluation of the antioxidant activity of several rosemary extracts Food Chemistry, 115(2): 740-744.

62. Tietz, N. (1995): Clinical Guide to Laboratory Tests, $3^{\text {rd }}$ ed AACC.
63. Ulbricht, C., Abrams, T.R., Brigham, A., Ceurvels, J., Clubb, J., Curtiss, W., Kirkwood, C.D., Giese, N., Hoehn, K., Iovin, R., Isaac, R, Rusie, E., Serrano, J.M., Varghese, M., Weissner, W. and Windsor, R. C. (2010): An Evidence-Based Systematic Review of Rosemary (Rosmarinus Officinalis) by the Natural Standard Research Collaboration. Journal of Dietary Supplements, 7(4): 351-413.

64. Varga, T., Czimmerer, Z. and Nagy, L. (2011): PPARs are a unique set of fatty acid regulated transcription factors controlling both lipid metabolism and inflammation. Biochim. Biophys. Acta, 1812(8): 1007-1022.

65. Venkateshan, S., Subramaniyan, V., Chinnasamy, V. and Chandiran, S. (2016): Anti-oxidant and anti-hyperlipidemic activity of Hemidesmus indicus in rats fed with highfat diet. Avicenna J. Phytomed., 6(5): 516525.

66. Zheng, T., Moss-Pierce, T., Ford P. and. Jiang T. A (2013): Rosemary (Rosmarinus off icinalis L.) Extract Regulates Glucose and Lipid Metabolism by Activating AMPK and PPAR Pathways in HepG2 Cells Agric. Food Chem., 61: 2803-2810. 


\section{تأثير مستخلص إكليل الجبل علي السمنة المستحثة بالحمية عالية الدهن لدى ذكور الجرذان البيضناء البالغة البة البهاه}

\section{إبراهيم محمد شتثله1 ـ عامر محمد عبد الحميد² ـ محمود متولي3}

أقسام الفسيولوجيا الطبية1 والكيمياء الحيوية2 والفارماكولوجيا3 ـ كلية الطب ـ جامعة الأزهر ـ مصر

خلقيـة البحث: السـنة واحدة من أخطر المثـاكل الصـحية العالمية في القرن الحـادي و العثـرين، وتعتبر عامل الخطر الرئيسي في بدء مختلف الأمراض المزمنة غير المعدية مثن إختلال دهون الدم، وتصلب الثرايين، و أمر اض القلب و الأوعية الدموية، و داء السكري.

الهدف من البحث: تقييم تأثثر مستخلص إكليل الجبل على الكوليسترول في الدم، و اتش دي ال، و ال دي ال، و تر ايجلسـر ايد، و الجلوكـوز والإنسـولين و النشـاط الإنزيمسي فـي مصـل الـدم للجلوتـاثيون بيروكسيداز ، وسوبر أكسيد ديسميوتاز، و الكاتـالاز، و كذللك وزن الجسم، و مؤشر السمنة، و مقاومـة الإنسولين في جرذان الحمية عالية الدهن.

مواد وطرق البحث: تم تصنيف أربعين مـن الجرذان البيضـاء من السـلالة المحلية عثو ائبا إلى أربع مجمو عات و تم تغذية المجمو عـة الأولى على النظام الغذائي الأساسي حيث تلقت 0.2 مل من المـاء المقطر يوميا عن طريق انبوب الفم والإحتفاظ بها كمجمو عة المقارنة .أما المجموعة الثانيـة فقد غذيت على النظام الغذائي الأساسي وتلقت مستخلص إكليل الجبل (100 ملغم /كغم من وزن الجسم يوميا عن طريق أنبوب الفم)، وتمت تغذيـة المجموعـة الثالثة على الحمية عاليـة الدهن وتلقت 0.2 مل من الماء المقطر عن طريق أنبوب الفم، وتمت تغذية المجموعة الرابعة على نظام الحميـة عاليـة الدهن مـع مستخلص إكليل الجبل (100 ملغم / كغم من وزن الجسم يوميا عن طريق أنبوب الفم).

النتائج: أظهرت جرذان الحمية عالية الدهن زيادة معنوية في وزن الجسم، وكوليسترول الام، و ال دي ال، و نر ايجلسـر ايد، و الجلوكـوز الصـائم والإنسـولين، و انخفـاض معنـوي في اتش دي ال المصـل، وجلوتاثيون بيروكسيداز و سوبر أكسيد ديسميوناز و الكاتالاز بالمقارنة مع مجمو عة المقارنة.

و أظهرت جرذان الحمية عالية الدهن مع مستخلص إكليل الجبل انخفاض معنوي في وزن الجسم، و الكوليسترول في الدم، و ال دي ال، و تر ايجلسر ايد، و الجلوكوز، والأنسولين، وزيـادة معنويـة في 


\section{IBRAHIM M. SHATLA et al}

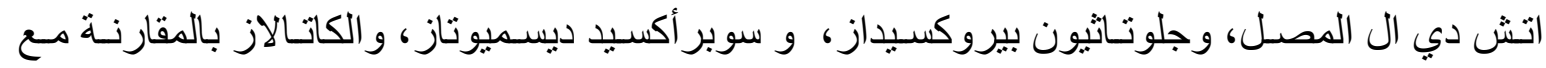

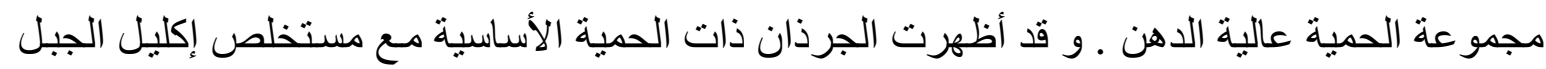

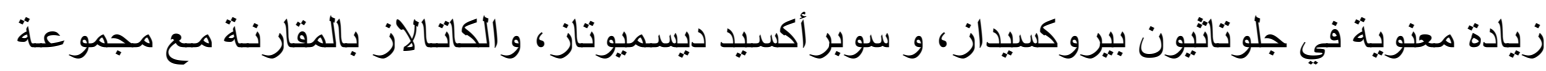

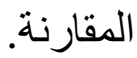

الخلاصة: أظهر مستخلص إكليل الجبل زيادة الأنشطة التأكسدية، وجلوتاتيون بيروكسيداز، وسوبر أكسيد ديسميوناز ، والكاتـالاز في مصل الـم وكذلك تحسين دهـون الـدم ، و إنخفاض الجلوكوز ، و الإنسولين و وزن الجسم و مؤشر السمنة، ومقاومة الإنسولين في فئران الحمية عالية الدهن. 